The Tangled Field 



\section{The Tangled Field}

Barbara McClintock's Search for the Patterns of Genetic Control

\section{Nathaniel C. Comfort}


Copyright (C) 2001 by Nathaniel C. Comfort

All rights reserved

Printed in the United States of America

Second printing, 2003

First Harvard University Press edition, 2003

Library of Congress Cataloging-in-Publication Data

Comfort, Nathaniel C.

The tangled field : Barbara McClintock's search for the patterns of genetic control / Nathaniel C. Comfort.

p. $\mathrm{cm}$.

Includes bibliographical references and index.

ISBN 0-674-00456-6 (cloth)

ISBN 0-674-01108-2 (paper)

1. McClintock, Barbara, 1902-1992. 2. Women geneticistsUnited States-Biography. I. Title.

QH429.2.M38 C66 2001

$576.5^{\prime} 092-\mathrm{dc} 21$

[B] 00-069712 
To Valborg, Lanny, Lowise, Honore, Susan, Carol, Ruth, Jane, and now Gwendolyn 
